MEDICINE AND THE ENVIRONMENT

\title{
Health and fracking: Should the medical profession be concerned?
}

\author{
R Mash, J Minnaar, B Mash
}

Rev. Dr Rachel Mash is the environmental co-ordinator of the Anglican Church of Southern Africa. She holds a PhD in Family Medicine from Stellenbosch University, South Africa. Jolynn Minnaar is a journalist and director of Unearthed - an independent, international 18-month investigation into shale gas extraction and the fracking process. Prof. Bob Mash is the Head of Family Medicine and Primary Care, Stellenbosch University, South Africa, and chairs the faculty committee on sustainable development.

Corresponding author: R Mash (rmash@mweb.co.za)

The use of natural gas that is obtained from high-volume hydraulic fracturing (fracking) may reduce carbon emissions relative to the use of coal and have substantial economic benefits for South Africa. However, concerns have been raised regarding the health and environmental impacts. The drilling and fracking processes use hundreds of chemicals as well as silica sand. Additional elements are either released from or formed in the shale during drilling. These substances can enter the environment in various ways: through failures in the well casing; via alternative underground pathways; as wastewater, spills and leaks on the wellpad; through transportation accidents; and as air pollution. Although many of these chemicals and elements have known adverse health effects, there is little evidence available on the health impacts of fracking. These health concerns have not yet been fully addressed in policy making, and the authors recommend that the voice of health professionals should be part of the public debate on fracking and that a full health impact assessment be required before companies are given the go-ahead to drill.

S Afr Med J 2014;104(5):332-335. DOI:10.7196/SAMJ.7860

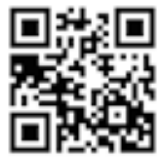

South Africa (SA) is about to embark on exploratory high-volume hydraulic fracturing (fracking) to extract the huge reserves of natural gas contained in shale rock. ${ }^{[1]}$ There has been much controversy around this decision as, on the one hand, this could reduce our carbon footprint (natural gas releases 58\% less carbon dioxide than coal) and could have significant economic benefits for the country; while, on the other hand, there are concerns about the environmental and health impacts. ${ }^{[2]}$ Some countries, such as France and Bulgaria, have banned fracking, while others such as the UK believe that it can be performed safely if regulations are strictly enforced. ${ }^{[3]}$ The USA has been one of the leaders in fracking, which has transformed their reliance on imported fossil fuels, although some states, such as New York, are calling for a comprehensive health assessment before giving permission. ${ }^{[4]}$ Although fracking has been taking place for a decade in the US, there is surprisingly little scientific evidence on the health impacts. It cannot be concluded that an absence of evidence of harm implies that no harm may result. ${ }^{[5]}$ This article attempts to summarise the health concerns and discuss them within the SA context.

\section{The current situation}

Permission has been granted to initiate exploratory fracking in an area of $>200000 \mathrm{~km}^{2}$ in SA, which will affect the Karoo, parts of the Free State, Northern and Eastern Cape, and a portion of KwaZuluNatal. If the gas deposits are found to be financially viable, thousands of wells could potentially be drilled in these areas. ${ }^{[6]}$

\section{Additives used in the drilling and fracking process}

Hundreds of chemicals are used during the drilling and fracking phases, but access to information on the chemical constituents has been limited due to protection under proprietary legislation. Table 1 shows some of the known chemicals and the purposes for which they are used. Fig. 1 presents data on 353 of the known chemicals and the percentage of these associated with a variety of potentially adverse effects on health; ${ }^{[7]} 77$ of them (Table 2) are associated with $\geq 10$ potential adverse health effects. ${ }^{[7]}$

Silica sand is used to keep open the network of tiny spaces in the shale created by fracking, which allow the gas to be released. Each well requires up to 2000 tons of sand for the fracking process. The US National Institute for Occupational Safety and Health reported that 92/116 air samples obtained from fracking sites in five states exceeded the recommended safe levels for silica. ${ }^{[2]}$ Exposure of workers to silica over several years may result in silicosis, an irreversible lung disease associated with an increased susceptibility to tuberculosis.

\section{Elements accessed during drilling and fracking}

In addition to the chemicals used during drilling and fracking, elements inherent in the shale layer are also accessed and brought to the surface during gas extraction. Some are known or suspected carcinogens, endocrine disruptors or substances otherwise toxic to humans. Heavy metals such as arsenic, mercury, chromium, barium and lead, and naturally occurring radioactive matter (NORM) such as uranium and strontium, have been identified. ${ }^{[8]}$ According to the US Centers for Disease Control, such toxic exposure can result in 'anemia, cataracts, cancer and increased mortality.[9] The potential health risks in the long term need to be considered, as many diseases such as cancer appear after years of exposure. ${ }^{[5]}$

\section{Risks of exposure}

In SA, water is a scarce resource with $98 \%$ of available water already allocated. ${ }^{[10]}$ Yet, it has been calculated that up to 29 million 
litres of water may be needed for a single well, of which up to 250000 litres may consist of chemicals. ${ }^{[3]}$ There are several ways in which these chemicals might enter the environment: through a failure in the well casing; via alternative underground pathways; as wastewater, spills and leaks on the wellpad; through transportation accidents; and by polluting the air.

\section{The well casing}

The cement and steel casing around the wellhead, where the borehole meets the surface, needs to be constructed so that no chemicals exit the well - whether during drilling or fracking, when producing gas, or after the well has been declared exhausted and has been abandoned. Current well design and capping technology uses steel that may rust and concrete that can crack. The majority of cases of groundwater contamination have been caused by inadequate cementing or casing. ${ }^{[3]}$ These failures may represent migratory pathways for chemicals to reach surrounding water aquifers.

Assertions regarding the flammability of drinking water have been made in the mass media and a study has indicated that drinking water wells within a $1 \mathrm{~km}$ radius of a drilling site have a 17 times increased concentration of methane. ${ }^{[2]}$ Methane can leak as a result of improperly constructed wells, poor gas capture or, less commonly, hydraulic fractures. ${ }^{[3]}$ Although methane is not toxic to humans and small amounts can normally be present in drinking water, it is flammable and could build up to explosive levels. ${ }^{[11]}$
One further study also pointed to the danger of workers being exposed to radon, which is a risk factor for lung cancer. The radon present in shale may mix with the methane as it escapes. The concentrations examined in Marcellus shale were up to 70 times the average from other natural gas wells throughout the USA. ${ }^{[12]}$

It should also be noted that fracking increases the risk of local earth tremors, which have the potential to disrupt the well casing; one such incident was reported in the UK where, during exploratory fracking, the well casings were deformed by the tremor. ${ }^{[13]}$

\section{Alternative underground pathways}

Most geologists report that the chemicals that remain in the shale bed are effectively sealed off from the groundwater by the depth of drilling and layers of impervious rock. However, some scientists who have studied the unique geology of the Karoo, with its widespread intrusion of dolerite dykes and sills, have expressed concern that there exists the possibility of contaminants reaching the groundwater system. ${ }^{[14]}$

\section{Wastewater}

While water does remain in the shale, $\sim 30$ $60 \%$ of the fluid returns to the surface once the well has been fracked. This flowback is laced with the injected chemicals and elements derived from the shale. These 'produced' fluids can contain heavy metals, salts and NORM from below ground. The chemicals used in fracking vary in toxicity; some are known or suspected carcinogens, endocrine disruptors or additives otherwise toxic to humans, including benzene, ethylene glycol, methanol, lead, boric acid and $\gamma$-emitting isotopes. ${ }^{[3]}$

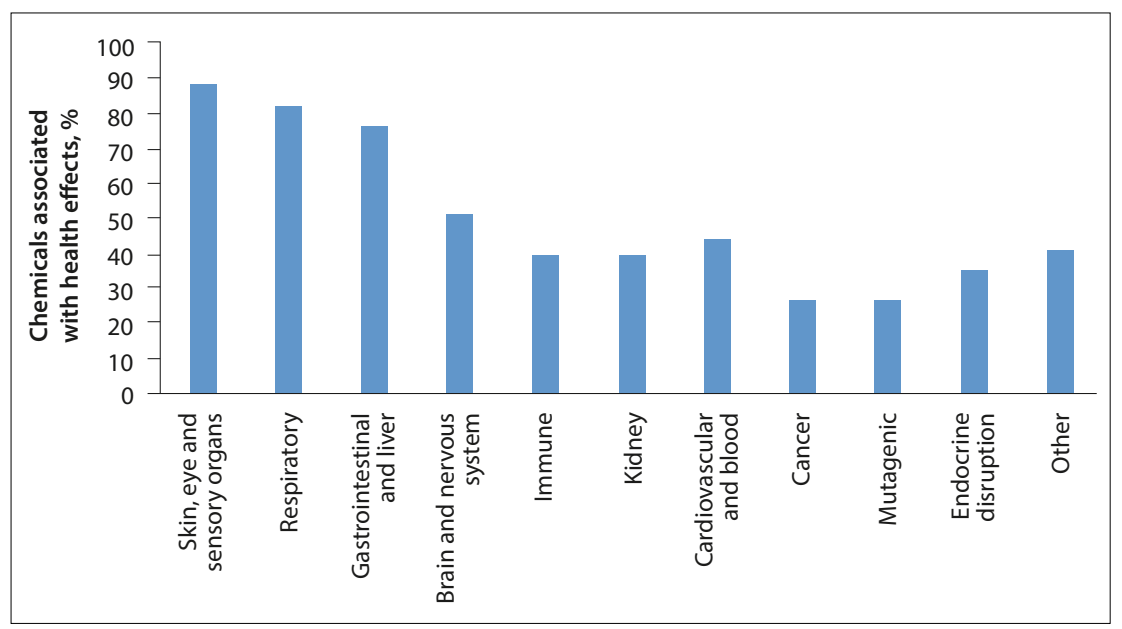

Fig. 1. Possible health effects of the 353 chemicals used in natural gas operations.

Table 1. Types of chemicals and additives used in the fracking process

\begin{tabular}{|c|c|c|}
\hline Additive type & Description/purpose & Examples of chemicals \\
\hline Proppant & 'Props' open fractures to allow gas to flow freely & Silica sand, zirconium oxide, ceramic beads \\
\hline Acid & To dissolve clay to allow the gas to flow & Hydrochloric acid (3 - 28\%) \\
\hline Breaker & $\begin{array}{l}\text { Reduces the viscosity of the fluid to release the proppant } \\
\text { into the fractures }\end{array}$ & Peroxydisulphates \\
\hline Bactericide/biocide & Inhibits growth of organisms that could contaminate methane & Glutaraldehyde: 2-bromo-2-nitro-1,2-propanediol \\
\hline Buffer & Adjusts and controls the $\mathrm{pH}$ & Sodium or potassium carbonate \\
\hline Clay stabiliser & Prevents swelling of clay which might block pores & Tetramethyl ammonium chloride \\
\hline Corrosion inhibitor & Reduces rust formation on well casings & Methanol, ammonium bisulphate \\
\hline Crosslinker & $\begin{array}{l}\text { Increases the viscosity of the fluid so that it can carry } \\
\text { more proppants }\end{array}$ & Potassium hydroxide, borate salts \\
\hline Friction reducer & Allows fluids to be injected at optimum rates & $\begin{array}{l}\text { Sodium acrylate-acrylamide copolymer, } \\
\text { polyacrylamide }\end{array}$ \\
\hline Gelling agent & Increases viscosity of fluid & Guar gum, petroleum distillate \\
\hline Iron control & $\begin{array}{l}\text { Prevents precipitation of carbonates, which could plug off } \\
\text { the formation }\end{array}$ & Ammonium chloride, ethylene glycol, polyacrylate \\
\hline Solvent & Used to control the wettability of contact surfaces & Aromatic hydrocarbons \\
\hline Surfactant & Reduces fluid surface tension thereby aiding fluid recovery & Methanol, isopropanol, ethoxylated alcohol \\
\hline
\end{tabular}


Table 2. Natural gas drilling and hydraulic fracturing chemicals with $\geq 10$ adverse health effects

\begin{tabular}{|c|c|c|}
\hline (2-BE) Ethylene glycol monobutyl ether & Ethanol (acetylenic alcohol) & Naphthalene \\
\hline 2,2',2"-Nitrilotriethanol & Ethyl mercaptan & Natural gas condensates \\
\hline 2-Ethylhexanol & Ethylbenzene & Nickel sulphate \\
\hline 5-Chloro-2-methyl-4-isothiazolin-3-one & Ethylene glycol & Paraformaldehyde \\
\hline Acetic acid & Ethylene glycol monobutyl ether (2-BE) & Petroleum distillate/naptha \\
\hline Acrolein & Ethylene oxide & Phosphonium, tetrakis(hydroxymethyl)-sulphate \\
\hline Acrylamide (2-propenamide) & Ferrous sulphate & Propane-1,2-diol \\
\hline Acrylic acid & Formaldehyde & Sodium bicarbonate \\
\hline Ammonia & Formic acid & Sodium bromate \\
\hline Ammonium chloride & Fuel oil \#2 & Sodium chlorite (chlorous acid, sodium salt) \\
\hline Ammonium nitrate & Glutaraldehyde & Sodium hypochlorite \\
\hline Aniline & Glyoxal & Sodium nitrate \\
\hline Benzyl chloride & Hydrodesulphurised kerosene & Sodium nitrite \\
\hline Boric acid & Hydrogen sulphide & Sodium sulphite \\
\hline Cadmium & Iron & Styrene \\
\hline Calcium hypochlorite & Isobutyl alcohol (2-methyl-1-propanol) & Sulphur dioxide \\
\hline Chlorine & Isopropanol (propan-2-ol) & Sulphuric acid \\
\hline Chlorine dioxide & Kerosene & \multirow{2}{*}{$\begin{array}{l}\text { Tetrahydro-3,5-dimethyl-2H-1,3,5-thiadiazine-2- } \\
\text { thione (Dazomet) }\end{array}$} \\
\hline Dibromoacetonitrile 1 & Light naphthenic distillates, hydrotreated & \\
\hline Diesel 2 & Mercaptoacetic acid & Titanium dioxide \\
\hline Diethanolamine & Methanol & Tributyl phosphate \\
\hline Diethylenetriamine & Methylene bis(thiocyanate) & Triethylene glycol \\
\hline Dimethyl formamide & Monoethanolamine & Urea \\
\hline Epidian & Naphtha, petroleum medium aliphatic & Xylene \\
\hline
\end{tabular}

\section{Accidental spills}

It is estimated that each well will require transportation of freshwater, chemicals and wastewater by at least 1500 trucks or tankers. ${ }^{[6]}$ Given the number of trucks, inexperienced drivers and poor state of many roads, there is a very real possibility of accidents, blowouts or spills. Spills are also common on the wellpad where substantial amounts of diesel and the fracking additives are handled and can potentially contaminate local water sources. ${ }^{[3]}$

\section{Air pollution}

Toxic compounds mix with the escaping methane and the nitrogen oxides from the exhaust of diesel trucks to produce ground-level ozone. Ozone combines with particulate matter $<2.5 \mu \mathrm{m}$ and produces smog thereby creating air pollution, which can spread up to $200 \mathrm{~km}$ from the production area. A combination of evaporation from the toxic waste ponds, venting and flaring of escaping methane gas from the wells, and the exhaust from trucks and industrial equipment further impairs air quality and contributes to the smog. Dust pollution also arises from the large-scale transportation of water and chemicals on gravel roads. ${ }^{[15]}$ Up to $37 \%$ of the chemicals used in the processes are volatile, with the ability to become airborne with subsequent inhalation, ingestion or absorption through the skin. ${ }^{[8]}$ The US Environmental Protection Agency reports that chronic inhalation may result in headaches, insomnia, gastric disturbances, conjunctivitis, visual disturbances and blindness. ${ }^{[1]}$ Although the impact of individual wells on air quality may be low, the cumulative impact of a number of wellpads may be significant. ${ }^{[3]}$

\section{Risk management}

While fracking is undoubtedly associated with many potential health problems, some would argue that these risks can be contained with sufficient regulation. ${ }^{[3]}$ Oil, gas and energy companies, however, do not have a good track record when it comes to avoiding pollution on the African continent. Under SA law, hazardous waste management is a provincial responsibility. The majority of fracking is likely to take place in the Eastern Cape, an under-resourced province with poor administration.$^{[6]}$ In SA, there is a concern that regulations will be less strictly adhered to than in well-resourced settings.

\section{Conclusion}

Fracking may indeed have substantial benefits for the SA economy. However, the environmental and health impacts may not be insignificant and these have yet to be considered in sufficient depth. To reduce possible negative public health impacts, a precautionary approach should be adopted and provision made for monitoring and adaptation. ${ }^{[2]}$ The voice of the health profession should be part of the debate and a full health impact assessment required before companies are given the go-ahead to drill. Without strictly enforced regulations in place, it would be irresponsible to allow an industry on this scale to be launched. 
1. Department of Mineral Resources. Mineral and Petroleum Resources Development Act, 2002 (Act No. 28 of 2002). Proposed Technical Regulations for Petroleum Exploration and Exploitation. Government Gazette, 15 October 2013. https://db3sqepoi5n3s.cloudfront.net/files/131015technicalregulationforpe troleum pdf (accessed 27 February 2014)

2. American Public Health Association. The Environmental and Occupational Health Impacts of HighVolume Hydraulic Fracturing of Unconventional Gas Reserves. Policy No. 20125, 30 October 2012 http://www.apha.org/advocacy/policy/policysearch/default.htm?id=1439 (accessed 27 February 2014). 3. Public Health England. Review of the Potential Public Health Impacts of Exposure to Chemical and Radioactive Pollutants as a Result of Shale Gas Extraction. London: PHE, 2013. http://www.hpa.org uk/webc/HPAwebFile/HPAweb_C/1317140158707 (accessed 27 February 2014).

4. Concerned Health Professionals of New York. Call for a comprehensive health impact assessment. http://concernedhealthny.org/call-for-a-comprehensive-health-impact-assessment/ (accessed 27 February 2014).

5. Finkel $\mathrm{M}$, Hays J. The implications of unconventional drilling for natural gas: A global public health concern. Public Health 2013;127(10):889-893. [http://dx.doi.org/10.1016/j.puhe.2013.07.005]

6. Fig D. Hydraulic fracturing in South Africa: Correcting the democratic deficits. In: Daniel J, Naidoo P, Pilly P Southall R eds. New South Africa Review 3. Joh hes dorg: Wits University Press, 2013:173-194. Pillay P, Southall R, eds. New Soch Afrca Revew 3. Johannesburg: Wits University Press, 2013:173-194 7. Colborn T, Kwiatkowski C, Schultz K, Bachran M. Natural gas operations from a public health perspe
Hum Ecol Risk Assess 2011;17(5):1039-1056. [http://dx.doi.org/10.1080/10807039.2011.605662]

8. Lauver, L. Environmental Health Advocacy: An overview of natural gas drilling in Northeast 8. Lauver, L. Environmental Health Advocacy: An overview of natural gas drilling in Northeast
Pennsylvania and implications for pediatric nursing. J Pediatr Nurs 2012;27(4):383-389. [http://dx.doi. Pennsylvania and implications for
org/10.1016/j.pedn.2011.07.012]
9. Agency for Toxic Substances \& Diseases Registry; Centres for Disease Control. Toxicological Profile for Radium. http://www.atsdr.cdc.gov/ToxProfiles/tp.asp?id=791\&tid=154\#bookmark06 (accessed 27 February 2014).

10. Department of Water Affairs and Forestry. National Water Resource Strategy. Pretoria: DWA, 2004. http://www.dwaf.gov.za/Documents/Policies/NWRS/Default.htm (accessed 27 February 2014).

11. Sumi L. Environmental Concerns and Regulatory Initiatives Related to Hydraulic Fracturing in Shale Gas Formations: Potential Implications for North American Gas Supply. Ottawa: Council of Canadians, 2010. http://www.ontarioenergyboard.ca/OEB/_Documents/EB-2010-0199/Report_ Sumi_CoC.pdf (accessed 27 February 2014).

12. Resnikoff M. Radon in Natural Gas from Marcellus Shale. 10 January 2012. http://www.newyorkwater. org/pdf/Marcellus_Radon_copy.pdf (accessed 27 February 2014).

13. Torjesen I. Fracking poses little risk to public health, but evidence is limited. BMJ 2013;347:f6626. [http://dx.doi.org/10.1136/bmj.f6626]

14. Van Tonder G, de Lange F, Steyl G, Vermeulen D. Potential Impacts of Fracking on Groundwater in the Karoo Basin of South Africa. Bloemfontein: Institute for Ground a/sites/gwdorg za/files/04_G\%20vTonder_Potential\%20\%20Impacts\%200f\%20Fracking\%200n\%20 Gros

15. The Endocrine Disruption Exchange. Chemicals in Natural Gas Operations. http://endocrinedisruption. org/chemicals-in-natural-gas-operations/introduction (accessed 27 February 2014).

Accepted 31 January 2014 